\title{
Hiring of Forces and Security in the Arab Gulf: The Case of Private Security Companies in Qatar
}

\author{
Mohammed Salisu \\ Qatar University, Doha, Qatar
}

\begin{abstract}
Although literature abounds on the activities of private security companies (PSCs) in the Arab Gulf, how the PSCs hire their forces and the security threat it poses to the region have not been given the needed academic attention. In the Gulf sub-region where the PSCs rely solely on migrants to man their field operations, we ask how the forces are hired and its ramifications to the security of the state. In so doing, this article examines the operations of PSCs in the Gulf State of Qatar. It starts by highlighting the trends and trajectory of policing in Qatar and explains the reasons for the proliferation of PSCs in the conservative energy rich state. Second, it describes the procedures and processes used by the PSCs in hiring their forces. Third, it discusses the existing legal frameworks regulating the activities of the PSCs. The article concludes that the current situation where hiring of the field forces is undertaken by profit-oriented private institutions with little state supervision poses a threat to the peace and stability of the state in the long run.
\end{abstract}

Keywords: Qatar, West Africa, security forces, hiring, crime

\section{Introduction}

Academic discourse on security in the Arab Gulf has revolved around tribal rebellions, sectarian tensions, and intra- and inter-states conflicts. Related works have, thus, focused on how the ruling regimes in the sub-region have maintained internal stability through rentier policies (Beblawi \& Giacomo, 1987) and through the protection of global powers (Fulton \& Sim, 2019). In recent times, however, and with the surge in insecurity in Iraq since the US invasion, some works have focused on how the services of private security companies (PSCs) have been sought to provide security for diplomatic missions and foreign companies in the war-torn country. The employment of maritime security companies in the Gulf of Oman and the Gulf of Eden where piracy has been on ascendency has also received some attention. The influx of PSCs in the Gulf Cooperation Council (GCC) States of Saudi Arabia, Qatar, Kuwait, the United Arab Emirates, Oman, and Bahrain as a result of their tremendous economic growth snowballing their capitals into population density has also received some attention.

\footnotetext{
Acknowledgements: The author would like to thank Professor Mahjoob Zweiri, Professor of Gulf Politics and Security and the Director of the Center for Gulf Studies at Qatar University for his enormous supports towards the writing of this article. Despite his tight academic and administrative schedules, Professor Mahjoob read through the article on three occasions and offered useful suggestions and critical observations. It is prudent for the author to add it with his support that this article attained its [relative] perfection. All errors and omissions, however, remain the author's.

Mohammed Salisu, Ph.D. student, Center for Gulf Studies, Qatar University, Doha, Qatar.

Correspondence concerning this article should be addressed to Mohammed Salisu, Center for Gulf Studies, P. O. Box 2713, Qatar University, Doha, Qatar.
} 
Much as the activities of the PSCs in the Gulf sub-region are worth studying, their hiring processes and the threat it poses to the individual states have received no attention. Using a case study of Qatar, this article fills the vacuum by assessing the processes and procedures used by the PSCs in hiring their forces from West Africa. The article argues that it is the obligation of the State of Qatar to provide physical security to its citizens and residents and thus, the current situation where hiring of forces is undertaken by profit-oriented commercial agencies with little or no state supervision poses a threat to the security of the conservative tiny rich state.

A qualitative set data to elicit information about the hiring process was employed in this work. It is pertinent to mention that access to data from interested parties proved rather difficult. Whiles four of the five private security companies in Qatar turned down our request for interview, the one did exclude interview of their serving security forces. Similarly, the recruitment agencies in Ghana and Nigeria were also tight-lipped when we sought interview with them. This made the research recourse to available empirical methods that were conducted in three parts: interview with former security forces, management of a private security company in Qatar and a recruitment agency in Nigeria, and monitoring of radio advertisement for security job openings in Qatar.

The work begins with an outline of the trends and trajectories of policing in Qatar and reasons for the proliferation of PSCs in the state. The second section examines the procedures and processes used by the PSCs in hiring their forces from West Africa. The penultimate section is devoted to the prognosis in the light of legal tools employed by the State of Qatar in regulating the activities of the PSCs. The research concludes with a summary of the findings and offers recommendations.

The array of security institutions in Qatar has broadened from an initial focus on the police and army to include numerous private security agencies. The security sector is to Hendrickson (1999),

Those bodies that are responsible for, or should be responsible for, protecting the state and communities within it: this includes; (i) Groups with a mandate to wield the instruments of violence-military, paramilitary and police forces; (ii) Institutions with a role in managing and monitoring the security sector-civilian ministries and parliament; and (iii) non-governmental organizations and bodies responsible for guaranteeing the rule of law - the judiciary, the penal system, human rights ombudsmen and, where these bodies are particularly weak, the international community. (Hendrickson, 1999, p. 29)

This study focuses on the first group that enforces the law and the second group that wields the power of monitoring the activities of the former. The relevance of the study is, therefore, to demonstrate that internal security is and must be the responsibility of the Qatari State. This will make policy-makers pay more attention to the hiring processes of the PSCs operating within the country.

The study is premised on the hypothesis that effective scrutiny and monitoring of the hiring of private security forces would lead to enhanced security delivery and mitigate any prospective threat to the state. Theories of sovereignty and privatization are employed as the theoretical frameworks for the discussion.

\section{Theoretical Framework}

Since its origin, sovereignty has developed through several overlapping phases. The first, represented by the Treaty of Westphalia, is the initial phase when the sovereign reigned supremacy domestically and in its relations with the external world. The second, following World War II, marks the erosion of sovereignty with the development of democratic values and institutions. The third phase emerged as reactive claim of sovereignty by governments whose domestic performance renders them vulnerable to international scrutiny. 
The fourth is the contemporary realistic attempts at reconciling state sovereignty with responsibility (Deng, Kimaro, Lyons, Rothchild, \& Zartmann, 1996). It has been argued that sovereignty derives from three principal sources: "the degree of respect merited by an institution, the capacity to rule, and the recognition that the authority acts on behalf of and for the benefit of the people" (Onuf, 1991, pp. 425-446).

By the end of the 20th century, sovereignty increasingly came under harsh criticism. The nation-state paradigm has been frequently analyzed for its inadequacies in the post World War II period, since neither the institution itself nor the myths by which it endures are fully appropriate to the current conditions (Hertz, 1976). But even as the traditional concept of sovereignty erodes, there is no presumptive, let alone adequate, replacement for the state. The locus of responsibility for promoting citizens' welfare and liberty, for organizing cooperation and managing conflict, when not exercised by society itself, remains with the state and until a replacement is found, the notion of sovereignty must be put to work and reaffirmed to meet the challenges of the era in accordance with conventional standards of human dignity. "The spirit of sovereignty is not that the sovereign may do whatever it wishes...rather, it is the idea that, within the limits of its jurisdiction, no other actor may gainsay the will of the sovereign state" (Deng, Kimaro, Lyons, Rothchild, \& Zartmann, 1996, pp. 425-446). Thus, the obligation of the state to preserve life-sustaining standards for its citizens must be recognized as a necessary condition of sovereignty. This study is situated within this theory as it considers the Qatari State as having the final say in all matters within its boundaries. Sovereignty, therefore, requires the Qatari government to be responsible for [all] the activities of the PSCs operating within its boundaries.

Privatization, on the other hand, connotes several different processes, such as leasing, liquidation, and the transfer of ownership and assets from public to private hands. Cook and Kirkpatrick (1988) defined privatization as "a range of different policy initiatives designed to alter the balance between the public and private sector" ( p. 3). For Young (1991), privatization can be categorized into narrow and broad meanings. In its narrow meaning, "it simply entails a transfer of productive activities or services undertaken by the public sector to private ownership or control" (Young, 1991, pp. 50-62). In its broader meaning, however, "it refers to a process by which the state's role within the economy is circumscribed while at the same time the scope for the operation of private capital is consciously extended" (Young, 1991, pp. 50-62).

Privatization, in short, could be said to be a broad range of arrangements under which activities once engaged in by government are by varying degrees turned over to private hands. Proponents of privatization believe that the public sector is unwieldy and that many of the functions currently performed by governments should be better assigned to the private sector directly or indirectly. It is often argued that the private sector would perform these functions more efficiently, effectively, and economically than they can be performed by the public sector. Improvement in productivity, fiscal performance, and service delivery as well as the attainment of higher proceeds would be more likely to be better served under private than under state ownership. Privatization is, therefore, favored on the grounds that it depoliticizes decision-making as well as ends the mismanagement and corruption prevalent in enterprises and institutions controlled by the state.

Two distinct and quite different objectives are pursued in the name of privatization: "[T]hey are (i) the improvement of the delivery of goods and services by taking advantage of marketplace efficiencies and, alternatively, (ii) the reduction or termination of public support for particular goods and services altogether [sometimes called load shedding]" (Moe, 1989, pp. 659-672). The study is situated within the framework of the first case where privatization does not eliminate government accountability for the results of its expenditure; it basically shifts the locus of service delivery. In this case, though the State of Qatar allows PSCs to operate, it 
still has the responsibility of seeing to it that these organizations operate within the established frameworks. Put differently, the means of policy implementation is what the State of Qatar has privatized; but not the functional sphere of government action. What is relinquished is the easiest part-the doing. But the conceiving planning, goal-setting, standard-setting, performance monitoring, evaluation, and correction all remain with the government (Moe, 1989). The operations of PSCs in Qatar are ideally expected to follow this underlying principle of privatization.

To date, most securitization studies continue to consider the state or other governmental institutions as principal. Even for authors that highlight the securitization role of non-state actors, the state often remains the primary referent object. This has led Wilkinson (2007) to argue that "the 'Westphalian straitjacket' continues to shape theoretical and empirical research on securitization" (pp. 21-35). Thus, although Buzan, Wæver, and de Wilde (1998) repeatedly claim that securitization is not limited to state, their continual reference to "political" action and their own application of the theory privileges a state-dominated reading of security. Buzan et al. (1998) particularly acknowledged that though securitization is not "dogmatically state-centric in its premises", it is "often somewhat state-centric in its findings". Research by other authors, such as Phillip (2007), Kaliber (2005), and Sasse (2005) reveals similar predilection. For Sørensen (1996), states constitute the nexus when it comes to security for individuals and groups. Nonetheless, since small states especially those classified as "under populated" (which Qatar is part and parcel of) ${ }^{1}$ do not have the human capacity to provide all that is required of it, it is only logical for the states to allow PSCs to employ chunk of its security forces from abroad. The only caution is that the processes of hiring the forces ought to be scrutinized by the state to avoid thugs and bandits working within the fabrics of the PSCs.

\section{Migration and Trends in Policing in Qatar}

The Gulf Arab states appear to be moving along parallel internal security paths in varying degrees. The ensuing structure of economic and financial power-house of the monarchical states coupled with their scanty population has made them the focus of migration ${ }^{2}$. Exploration of energy resources for the half a century past and the ongoing economic reforms have influenced the inflow of foreign workers into the GCC State. Forstenlechner and Jane (2011) explained how "the ambitious development plans by the Arab Gulf rulers at the time of independence and the emergence of new nation-states required manpower and skills unavailable in the necessary quantity and quality at the time" (p. 32). This, according to them, led to the mostly unregulated import of mostly unskilled labor..."and after rapid development in the early seventies, the numbers of foreign residents rose exponentially" (p. 32). The laxity in the importation of cheap foreign labor from largely sub-Sahara Africa and South-East Asia "remains key pillars of the social contract between Arab Gulf rulers and the national business elite" (Forstenlechner \& Jane, 2011, p. 32). Thus, the GCC States are "demographically, labor-importing states, with expatriates accounting for a substantial proportion of the population" (Tsai, 2018, p. 3). Thus, the work force strength of the regular police in the individual states is woefully inadequate and thus requires the introduction of non-state security groups.

Prior to the introduction of professional policing in 1949, the State of Qatar had a system of maintaining peace and order. The social network was such that each was "his brother's keeper" and the traditionally

\footnotetext{
1 Information on the chronology of Qatari population is available at: https://www.mdps.gov.qa.

2 Being under populated with enormous energy resources, the GCC States have attracted extremely high proportion of migrant workers and the sub-region is considered the third largest in the world after the European Union and North America.
} 
established socio/cultural ethos and Islamic values were major tools for ensuring social control. Tribal heads and religious leaders regulated the social system for the prevalence of peace and security. But as the state evolves in earnest especially after the onshore discovery of oil in 1939 by the two British geologist, E. W. Shaw and P. T. Cox, "[T] he rulers of the State of Qatar gave particular importance for the mission of achieving public peace and security, a determination that led to the formation of the first police agency called the 'discipline police",. 3

The agency began working in 1949 at "Doha Police Station" located just around "Souq Waqif". The functions of this division comprised of providing security and protecting citizens and residents, ensuring discipline through patrols, undertaking permanent security protection at vital areas in the capital and ensuring traffic flow. It carried out [all] other police related functions such as criminal investigations, traffic offences, and referring offenders and accused persons to the courts, or ensuring their deportation if they are foreigners. ${ }^{4}$

The Qatari police force has, since then, performed such functions as were by law conferred upon personnel of the service and obeyed lawful orders and directions in respect of the execution of their duties. Again, the police undertook motto traffic duties to ensure safety on roads and the vetting and issuance of police criminal check certificates. Further, the normal day-to-night patrols in residential areas have continued to ward off criminals and ensure the requisite peace and tranquility in the state.

But the steady growth of the Qatari economy cum the exponential increase in its population from just about 112,000 people as at independence in 1971 to a bit more than one million in 2006 is the epiphany that struck the need for the deregulation of the security sector. Although the initiative does not suggest the regular police lacks the necessary savvy to ensure law and order, the policy has craftily wiggled the state out of the necessity of hiring more personnel into the regular police to undertake duties that can be done effectively, efficiently, and at a cheaper cost by the private security forces. Again, the accessibility and affordability in obtaining the services of PSC forces makes it disincentive to strengthen the work force of the regular police. Several government institutions, individuals, and private limited liability companies have continued to contract the services of PSCs in the state. This is what Abrahamsen and Williams (2006) meant when they opine in their "Security Sector Reform" that,

It is not only because the private sector is often the key provider of security for large sections of society, but also because public and private security actors are inter-linked in crucially important ways, in terms of both personnel and services. (p. 4)

Overall, it is strategically important for the PSCs in Qatar to provide security services on the periphery whiles the regular police focuses on the core security mandate of the state. The above factors, among others, suggest the continuous liberalization of the policing regime in the state.

\section{Securing the Private Security Forces: Hiring Issues}

The process of hiring begins when there is instant demand for field forces or such demand is anticipated in the short term. ${ }^{5}$ Contacts are quickly made with recruitment agencies in Qatar who in turn contact their foreign

\footnotetext{
${ }^{3}$ Information available on the website of the Qatari Ministry of Interior in both Arabic and English languages. For obvious reason, I relied solely on the text in Arabic and did the translation into English myself. See: https://www.portal.moi.gov.qa.

${ }^{4}$ Ibid.

5 My interview with the head of recruitment section of Hemaya Security Services in Doha, Qatar, Mr. Ahmed Saoud M. Jassim, on Thursday, 28th of March 2019 in his office at 10:00 a.m.
} 
agents in the various West African countries. As a conservative state where males and females are segregated in many public spheres and functions, both sexes sought for the security job. But "the preference for tall and physically-built personnel remains the most demanded features". 6 And "whiles some of our clients placed request for male or female guards or mixture of both sexes, others demand for Arabic or English-speaking forces, a mixture of both or personnel with bi-lingual skills". ${ }^{7}$ Radio/FM stations and social media platforms are the means to reaching the young prospective forces.

Upon receipt of the request, the local recruitment agencies placed advertisements in the various media networks to reach the army of West African youths eager to migrate to the Gulf. ${ }^{8}$ The radio advertisements jingled in the Ghanaian local languages on daily basis are translated as:

Are you an energetic young man or woman desperately looking for job? Worry no more! A security company in Qatar, the city of Al Jazeera, is seeking workers to serve as security guards. The monthly salary is US\$1,500 in addition to free well-furnished accommodation, free health insurance and free three-square meal daily. Anybody who is healthy, has a valid passport and can read, speak, and write English can apply. All applicants shall pay for their flight tickets and visa fee. Interested persons should call this number (the number of the recruitment agency is given) for further and better details. ${ }^{9}$

To attract the needed personnel within the stipulated period, the adverts are colored with juicy incentives that do not exist. For example "If we tell them the truth as it is, only few uneducated Nigerians may want to travel and we will not get the number and caliber of people we are searching for". ${ }^{10}$

Table 1

Authors' Interview With 25 Nigerians and Ghanaians Apiece Who Served as Security Guards in Qatar From 2011 to 2016

\begin{tabular}{lll}
\hline Requirements for hiring & Former Nigerian security forces & Former Ghanaian security forces \\
\hline English proficiency & Required & Required \\
Strong physical appearance & Required & Required \\
Money for visa process & Required & Required \\
Money for flight ticket & Required & Required \\
Police criminal report & Not required & Not required \\
\hline
\end{tabular}

The concordance of empirical sources points to the fact that the hiring process is largely undertaken by private commercial entities in West Africa. With no criminal background check prior to the hiring, the situation creates an environment where thugs and bandits could be operating as forces in Qatar. Although there is relative peace and stability in West Africa, the sub-region is ridden in protracted communal violence, chieftaincy conflicts, and political militancy. The possibility, therefore, for hired forces to engage in one form of violence act is rife.

Examining contemporary security issues in West Africa where increase in drug related crimes, kidnappings, and armed robberies, Aning (2010) opined that, "although the majority of the criminals engaged

${ }^{6}$ Ibid.

${ }^{7}$ Ibid.

${ }^{8}$ Interview with the owner/director of Dan Lami Travel and Tours in Agege, Nigeria on the 15th of January 2019.

9 Between 8th and 13th January, the FM stations which I monitored in Accra, Ghana are: Peace FM, Oman FM, Adom FM and Asempa FM (broadcasting in the Twi language), and Marhaba FM (broadcasting in the Hausa language). While the Twi language is the most spoken Ghanaian language, the Hausa language is the lingua franca of the dwellers in the poor slum communities of the country.

${ }^{10}$ Interview with the director of Dan Lami Travel \& Tours. 
in these networks originated in the West African countries of Ghana and Nigeria, the networks have expanded their bases of operations beyond West Africa throughout the African continent" (p.2). He indicates that, "while crime has previously been perceived as states based, the activities of emerging criminal gangs and their networks now demonstrate the need for closer state collaboration and cooperation across national, sub-regional and regional frontiers and barriers" (Ibid).

As a tiny wealthy state, security in much of Qatar, in the broadest sense, is about protection against personal security, protection of property, access to justice, and resolution of community disputes, a phenomenon known as public good. Taught and argued about in the economic mainstream, public security quite aptly embodies both non-rivalry and non-excludability, reason why it ought to be produced and provided by the state (Hyman, 1983). This paper agrees with this argument but accepts the participation of PSCs in providing security under strict state supervision. The reason that state security is no longer the exclusive responsibility of public actors (Hyman, 1983). So, as Qatar is experiencing proliferation of PSCs, it is imperative to distinguish between the respective roles of public and private actors within the high policing paradigm. For the state retains the monopoly over the use of coercive force within its jurisdiction despite the coming in of private security organizations (Newburn \& Jones, 2002). Put differently, although there is continuity and change in policing in Qatar, this does not erode the sovereignty of the state. Thus, to help prevent the possibility of engaging criminals as security forces, the state must take special interest in the hiring processes.

\section{The PSCs and State Regulation}

The subtle operations of PSCs require lucid regulatory architecture to prevent security cavil. For on the face of it, the PSCs are mere commercial entities, but their activities and use of security guards who are far away from their countries of origin give credence to Moe's (1989) argument that, when it comes to matters of security, the conceiving planning, goal-setting, standard-setting, performance monitoring, evaluation, and correction must remain the prerogative of the state. The significance of Moe's theoretical framework is that, it differentiates between functional sphere of government action and policy implementation. Thus, for a modern and scientific understanding of what constitutes an efficient security delivery system, it is effective management and related institutions are necessary elements, mutatis mutandis, for a strong and stable Qatari State-society relationship.

Surfeited with regulatory powers, the Qatari ministry of interior ensures the PSCs are operating within the frameworks governing their establishment. Article 2 of Law No. 19 of $2009^{11}$ regulating the provision of private security services stipulates that "Private security services may not be provided unless by private security service companies in possession of necessary license from the Licensing Authority according to the provisions of this law. Such legal permission shall specify the licensed service or services". For Article 3 of the law, "The purpose of the licensed company under this law shall be only for the provision of private security services". Moreover, the law (in Article 9) requires that "The director responsible for the administration of a private security service company shall be a Qatari officer who had previously served in the police or armed forces or any other security service of the state". To avoid the usurp and presumptuous functions of the regular police, Article 13 of the law affirms that "Private security services personnel shall be prohibited from carrying firearms

11 Law No. 19 of 2009 regulating the provision of private security companies in Qatar. Available at: https://www.portal.moi.gov.qa. 
or modifying any part thereof unless authorized by the Minister". This particular legal provision bolsters the position of the regular police force as the puissance institution with overriding responsibility for internal security of the state. Last, the PSCs and their security guards are subjects to civil and criminal responsibilities and the State of Qatar may occlude their services and revoke their licenses when there is proven infraction of the law.

\section{Conclusion}

Thus far, the study has described the trajectory of policing in Qatar and examined the reason for the proliferation of PSCs in the conservative Gulf State of Qatar. The processes used for hiring security forces and the threat it poses to the state were also explored. The study indicated the phenomenal importance of the PSCs and discussed how they are regulated by the state. The article argues that the current procedure used in hiring the forces from West Africa threatens the security of the state in the long run.

As the population of Qatar continues to increase astronomically due to migration, the state has encouraged the operations of PSCs to compliment the efforts of the regular police. For "[T]he sheer presence and availability of private security guards in turn creates its own consumer dynamics, encapsulated in the seemingly insatiable demand for security in modern-day "risk society"' (Beck, 1992, p. 6). As corroborated by Gómez del Prado (2009), "the number of private security and military companies (PSMCs) which operate domestically and internationally is increasing due largely to the outsourcing of governmental functions" (p. 1). But he indicates that, PSMCs have been operating without proper supervision and accountability in countries with ongoing conflicts, such as Afghanistan, Colombia, and Iraq (Gómez del Prado, 2009). This study agrees with his assertion that PMSCs are generally not adequately supervised, although our examination was on the operations of private security companies in Qatar where there is peace and stability and hence, are being contracted not only by the state but by private individuals and organizations as well.

Although the State of Qatar is seen as a bulwark of stability in a region struggling to contain multiple groups of international migrants largely from sub-Sahara Africa and South East Asia, the operations of the PSCs in the state allow the regular police to pursue delivery of core security without being encumbered by personnel deficit. But the possible engagement of criminals as guards by the PSCs stokes concerns for the state to critically scrutinize their hiring processes. The profit-oriented approach of the recruitment agencies in West Africa and their disregard for criminal background check of the recruits creates the possibilities of past convicts and bandits being employed into the fabrics of the private security forces. In light of this, the quality and standards of monitoring the hiring processes of the PSCs become key. An efficient, well-regulated, and reliable security force can assist in the maintenance of law and order, and as such contribute in strengthening the stability of Qatar, its authority, and legitimacy. Conversely, hiring of criminals into the fabrics of the PSCs can contribute to insecurity, a development that could be detrimental to the peace and stability the state currently enjoys.

Last, the Qatari State must take special interests in protecting and ensuring the welfare of the private security forces. With the unflinching threats from its regional adversaries, the Qatari government must not only be seen ensuring the well-being of the regular police force, but also, and more importantly, the forces of the PSCs. The inadequacy in their conditions of service dips moral of personnel who mostly set off on an ambitious path to seeking greener pastures in a Gulf state flushed with cash with seemingly bottomless money, at least, as they were promised. 


\section{References}

Abrahamsen, R., \& Williams, M. (2006). Security sector reform: Bringing the private in. Conflict, Security and Development, 6(1), $1-23$.

Aning, K. (2010). International organized crime: The African experience-responses from regional organizations. Paper presented at the International Scientific and Professional Advisory Council (ISPAC) of the United Nations Crime Prevention and Criminal Justice Programme (UNODC), December 10-12, Courmayeur Mont Blanc, Italy.

Beblawi, H., \& Giacomo, L. (Eds.). (1987). The rentier state. London, UK: Taylor \& Frances.

Beck, U. (1992). Risk society: Towards a new modernity. London: SAGE Publications Ltd.

Buzan, B. G., Wæver, O., \& de Wilde, J. H. (1998). Security: A framework for analysis. Boulder, CO: Lynne Rienner Publication.

Cook, P., \& Kirkpatrick, C. (Eds.). (1988). Privatization in less developed countries: An overview. In Privatization in less developed countries. New York: Harvester Wheatsheaf.

Deng, F. M., Kimaro, S., Lyons, T., Rothchild, D., \& Zartmann, I. W. (1996). Sovereignty and responsibility. Washington D.C.: The Brookings Institutions.

Forstenlechner, I., \& Jane, E. (2011). The GCC's “demographic imbalance”: Perceptions, realities and policy options. Middle East Policy, 18(4), 25-43.

Fulton, J., \& Sim, L. C. (Eds). (2019). External powers and the Gulf monarchies. New York, NY: Routledge.

Gómez del Prado, J. (2009). Private military and security companies and the UN working group on the use of mercenaries. Journal of Conflict and Security Law, 13(3), 429-450.

Hendrickson, D. (1999). A review of security-sector reform. The Conflict, Security and Development Group Working Papers No. 1, Center for Defense Studies, King's College, London.

Hertz, J. H. (1976). The nation-state and the crisis of world politics: Essays on international politics in the twentieth century. New York: David McKay Publishing Co.

Hyman, D. (1983). Public finance: A contemporary application of theory to policy. Orlando: Harcourt.

Kaliber, A. (2005). Securing the ground through securitized "foreign" policy: The Cyprus case. Security Dialogue, 36(3), 319-337.

Moe, R. C. (1989). Exploring the limits of privatization. Public Administration Review, 47(6), 659-672.

Newburn, T., \& Jones, T. (2002). The transformation of policing? Understanding current trends in policing system. The British Journal of Criminology, 42(1), 129-146.

Onuf, N. G. (1991). Sovereignty: Outline of a conceptual history. Alternatives: Global, Local, Political, 16(4), 425-446.

Phillips, N. (2007). The limits of "securitization": Power, politics and process in US foreign economic policy. Government and Opposition, 42(2), 158-189.

Sasse, G. (2005). Securitizing or securing rights? Exploring the conceptual foundations of policies towards minorities and migrants in Europe. Journal of Common Market Studies, 43(4), 673-693.

Sørensen, G. (1996). Individual security and national security—The state remains the "principal problem". Security Dialogue, 27(4), 371-386.

Tsai, I. T. (2018). Political economy of energy policy reform in the Gulf Cooperation Council: Implications of paradigm change in the rentier contract. Elsevier: Energy Resource \& Social Science.

Wilkinson, C. (2007). The Copenhagen school on tour in Kyrgyzstan: Is securitization theory useable outside Europe? Security Dialogue, 38(1), 21-35.

Young, R. A. (1991). Privatization in Africa. Review of African Political Economy, 51, 50-62. 